\title{
Measuring Social Capital and Support Networks of Young Immigrants
}

\author{
María Paz Sandín Esteban ${ }^{1}$, Angelina Sánchez Martí ${ }^{1} \&$ Ana Belén Cano Hila ${ }^{1}$ \\ ${ }^{1}$ Faculty of Education, University of Barcelona, Barcelona, Spain \\ Correspondence: María Paz Sandín Esteban, Faculty of Education, University of Barcelona, Barcelona, 08035, \\ Spain. Tel: 34-93-403-5248. E-mail: mpsandin@ub.edu
}

\author{
Received: September 30, 2015 Accepted: November 5, 2015 Online Published: April 26, 2016 \\ doi:10.5539/ies.v9n5p62 \\ URL: http://dx.doi.org/10.5539/ies.v9n5p62
}

\begin{abstract}
This paper addresses the importance of the diagnosis of "personal communities" as relational systems that may influence the academic pathways of young immigrants. As part of a longitudinal study of the academic persistence of young people in their transition from compulsory to post-compulsory education, a "personal network questionnaire" has been developed. This instrument allows the relational structure of students to be captured and represented, and the impact of this structure on educational outcomes to be analysed. It measures and explores the network of inter-relations with adults (family, educational and recreational professionals, etc.) and peers in different settings. The theoretical elements underpinning its design and implementation are the interweaving of the student social capital and social support system to which they have or may have access to, and the Social Network Analysis (SNA) approach as the methodological framework. This network approach is rendered highly significant and valuable for professionals in educational diagnosis to assess relational vulnerability and design programs of intervention and counseling. With graphic techniques, we can somewhat address this challenge by examining patterns in relational data, experimenting with these data and putting forward hypotheses.
\end{abstract}

Keywords: social support, social capital, social networks, SNA, educational paths, immigrant students

\section{Introduction}

The debate on the educational success of all students continues to be a priority today, at least in sociopolitical and academic fields, as it relates to educational equality and social justice. In Spain, as in many other countries, there are serious disparities in academic achievement between native middle-class students and students from the largest immigrant groups (Gibson \& Carrasco, 2009). They form a complex group that integrates students with a highly diverse cultural background with different levels of previous schooling and competence in the official languages spoken in Barcelona (Spanish and Catalan). Students from North Africa have a lack of competence in Spanish and Catalan, a different religion and culture, a low-level profile of schooling in their home countries and certain competence in French. Instead, a student of Eastern Europe generally has a higher cultural level, in many cases is Catholic, has some knowledge of English, and by his/her phonetic system has a greater facility to learn Spanish and Catalan. Despite the heterogeneity of immigrant students, there are some general traits that influence their academic pathways: their previous schooling, their mother tongue, their chronological age, the time of year when they register for the host school, their language difficulties, etc. (Godoy, Suárez, \& Lucas, 2011).

Research shows that students from immigrant backgrounds in Spain have worse educational outcomes than their native peers, both in terms of accomplishment (final levels achieved) and performance (grades) (Serra \& Palaudàrias, 2010). Only $10 \%$ of immigrant students continue their education beyond the compulsory age of attendance, and there are relevant differences in terms of their academic continuity if nationalities are taken into account; the most likely to successfully complete compulsory secondary education appear to be students from Argentina (80\%) or Colombia (65\%), while students from Morocco (57.7\%) and Romania (53.5\%) show less probabilities of permanence (Martínez-Ambite, 2012). With regards to school performance, the data available in Spain confirms that immigrant students leave educational system earlier than their peers and, consequently, the number of foreign students enrolled at high educational levels is also lower, especially in post-compulsory schooling. 


\section{Immigrant Students and School Success}

Internationally recognised reports and evaluations, such as the Education at a Glance (OECD, 2014) and PISA (Programme for International Student Assessment (Ministerio de Educación, Cultura y Deporte e Instituto Nacional de Evaluación Educativa [Ministry of Education and National Institute of Educational Evaluation], 2013)), both by the OECD (Organisation for Economic Co-operation and Development), yield highly significant data which allow us to delve even further into the nature of this phenomenon. Both these publications have drawn the same conclusions.

First, evidence would suggest that access to education continues to be on the rise globally, especially in industrialised countries. However, the benefits of this expansion are not equally distributed. This means that socioeconomic divisions are increasingly more pronounced, particularly because the impact of education and skills in our lives, and opportunities, has greatly intensified. In post-industrial societies, the labour market rewards high educational levels and skills-but by no means erases unemployment-and penalises and marginalises those with lower academic achievements. In OECD countries in 2012, unemployment rates in the 25-34 years age bracket with higher education was around 7.4\% (4.6\% in 2008), while unemployment in this same age group without upper secondary education was $19.8 \%$ for this same year. These data confirm that the global economic recession that began in 2008 has hit those with lower training and skills levels more severely, and most especially young people.

Second, the power of education to act as a social mobiliser is discussed. These reports suggest that educational mobility, and consequently social mobility, is slowing down in industrialised countries. In fact, the reports highlight that the main risk for future growth is the deceleration or stagnation of upward social mobility. Therefore, they argue that governments should continue to improve universal access to education in order to build a more cohesive and prosperous society in the long term.

The third point raised is that the effect of parents' socioeconomic status and educational level in school performance emerges as significant. More specifically, the socioeconomic status of parents accounted for 7.9\% of the differences between good, intermediate and poor performance (OECD, 2014). In other words, the socioeconomic status of their families greatly affects students' academic results. Some theories, such as the sociology of education reproduction theory (Berstein, 1971, 1973; Bourdieu, 1986; Coleman, 1988; Fernández-Enguita, Mena, \& Riviere, 2010; Marí-Klose, 2014; Martínez-Celorrio \& Marín-Saldo, 2010), argue that students in privileged social strata have values and habits that favour classroom discipline and the acceptance of school values. This in turn inspires greater dedication and commitment from teachers, as well as all the other benefits associated with parents having greater cultural capital or material resources.

Some articles by Granovetter (1973), Putnam (1993) and Bridge (2004) challenge this argument on the strong influence or even determinism attributed to the family's cultural capital in relation to school performance of younger generations. These authors argue that family or inherited social capital continues to be effective today, but to a much lesser degree compared to previous times. They claim that the demise in the influence of family capital is contrasted with the increased influence of social capital. Many young people, they argue, surpass their inherited social position, at least in terms of academic and professional qualifications, rendering this inheritance less useful than it would have been in the past. Now, it would appear that this is being replaced by students creating their own network of personal and social contacts.

In addition to this growing attenuation of inherited social capital, in terms of social mobility, various papers (Gil-Calvo, 2009; Weller \& Bruegel, 2009) affirm that academic qualifications are no longer sufficient. This can be explained in part by the increasing devaluation of academic credentials and an over-qualified workforce, both of which weigh heavily on the job opportunities for young people. Therefore, the future of generations to come can no longer be forecast with any great certainty depending on their family background, as occurred during the industrial age. Nor can it be ensured through personally incorporated human capital through education and training, as is the case in meritocratic social systems. Now the future of new generations follows an uncertain course that depends on various factors: cyclical variations in the labour market, educational reforms and the social networks that young people themselves are capable of weaving (Cano, 2011; Urban, 2009). In other words, the key to moving up the social ladder is now envisioned as a combination of academic and professional qualifications (knowledge and skills) and social capital (the ability to access to institutional resources through one's social relationships).

Considering the above, we can therefore understand that one of the greatest challenges facing the educational world is to plan, develop and evaluate socio-educational activities that modulate the configuration of students' social networks and social capital, particularly the most vulnerable, in order to promote greater equality and social 
cohesion (Cano, Sánchez, \& Sandín, 2014). Schools, therefore, as well as being centres for the transmission of curricular knowledge, also emerge as a context and a key factor in promoting the construction of relational social capital, which is especially valuable for students from low socioeconomic strata or socially disadvantaged. The school, thus, facilitates students', especially socially vulnerable students', access to cultural and educational activities that otherwise would not be provided by their families. It equips students with extra social capital by coordinating "functional communities", which act as, within and between schools, structured social interaction systems. This ensures that the positive atmosphere created extends beyond the school itself through residential proximity and participation in shared social interaction networks (Salido, 2007, p. 33). Consistent with this emerging role of the school as a generator of social capital, it is important to specify that educational professionals should not only consider the configuration of each person's personal network, but also the type of social capital that this person is capable of orchestrating and the potential social support or resources that he or she may have access to (Sandín \& Pavón, 2011).

To sum up then, our point of departure is the increasing importance in today's society of education and the construction of educational and social capital, on the one hand; the role of educational centres as spaces to promote interaction, on the other. And finally, the increasing attention paid to the analysis of networks and social capital in educational research. As the fruit of these elements, we describe the process involved in the construction and design of a measuring instrument, a personal network questionnaire. The primary purpose of this tool is to capture and represent the relational structure of students from immigrant families and, secondly, to assess the impact that this has on their educational pathways. Thus, the questionnaire measures and explores relational social capital and how this might relate to social support (emotional, informational, material, and academic) and school performance.

The article (Note 1) is structured as follows: firstly, a brief description of the theoretical basis underpinning the design and elaboration of the instrument. Then, we outline its design features, including the aims, dimensions and indicators, the sample population and how it is applied, as well as highlighting its potentials and limitations.

\section{A "Personal Network Questionnaire": Theoretical Basis for an Instrument}

The assumptions guiding and underpinning the design of the network tool are based on two conceptual dimensions: i) the concepts of social capital and social support; and, ii) the Social Network Analysis (SNA) approach as a theoretical, methodological and instrumental framework.

\subsection{Social Capital and Social Support}

First, the concept of social capital is not without controversy. It has raised much debate across various social science disciplines, but especially as it relates to social inequality, social integration and exclusion, particularly of the immigrant community, school success and/or failure, among others. Many of the contributions to this debate support the idea that social ties or relationships help improve individual well-being as well as the better functioning of society.

The current paper situates the construct of social capital in Bourdieu's (1986) approach, a critical structural view that is essentially seen as access to institutional resources. Thus, Bourdieu conceptualizes social capital as the aggregate of actual or potential resources linked to possession of a durable network of essentially institutionalized relationships of mutual acquaintance and recognition. Through social capital, actors can gain direct access to economic resources (i.e. subsidized loans); they can increase their cultural capital through contacts with experts or individuals of refinement (i.e. embodied cultural capital); or, alternatively, they can affiliate with institutions that confer valued credentials (i.e. institutionalized cultural capital) (Portes, 1998, p. 4).

Several research lines are currently exploring the relationship between social capital and emigration. Some explore the association between educational success/failure and the social integration of immigrants; how this might relate to their networks and social supports that function as a resource in many situations; such as finding, keeping or improving employment; academic achievements; emotional support and obtaining social assistance (Gualda, 2004; Martínez, García, \& Maya-Jariego, 2001; Portes, 1995). Most of these studies argue that the development of social capital allows, on the one hand, better integration of immigrant groups in the host society, and on the other hand, can be used to explain how the young immigrant adjusts to the school setting, thus acting as a predictor of school success (Chow, 2000; Portes \& MacLeod, 1999).

Secondly, the definition of social support is taken as theoretical basis, another complex concept around which more and more studies in this area are being conducted. Social support is basically understood as a set of emotional and instrumental resources which are provided through the interaction with others, and that help the individual to get adjusted to his/her environment. In this sense, it has been shown to have an impact on 
well-being, health, integration, among other aspects in a person's life (Caplan, 1974; Lin, 1986; Maya-Jariego, Martínez, \& García, 1999; Gracia, Herrero, \& Musitu, 2002; López et al., 2007).

Lin (1986), who understands support as perceived or actual instrumental and/or expressive provisions coming from others, delineates three layers of social relations that act as different sources of social support and provide different feelings of bonding and aid. The outer layer refers to the community that gives the individual a sense of belongingness to a larger social structure; social networks providing feelings of attachment. The intermediary layer is characterized by social networks-strong and weak ties-that generally share information and resources. And, finally, the inner most layer is characterized by intimate trusting relationships. Such sphere of intimacy and trust derives feelings of commitment to others, which implies the adoption of norms of reciprocity and some responsibility for their well-being.

Thus, research has shown that there are differences between the various subtypes of support and that those are necessary to capture the functionality of networks. Much of the literature, and the work of Barrera (1980) and Bravo and Fernandez (2003) in particular, argue that social support can be mainly divided into emotional support (i.e. reassurance), instrumental support (i.e. tangible help) and informational support (i.e. advice), although other categorizations have been conceptualized. For instance, Gottlieb (1978) suggested five different types of social support: emotional, sustaining behaviour, indirect personal influence, problem-solving behaviour, and environmental action on the individual's behalf; whereas Barrera and Ainley (1983) identified six types of social support: material aid, behavioural assistance, intimate interaction, guidance, feedback, and positive social interaction.

\subsection{The Social Network Analysis (SNA)}

The Social Network Analysis (SNA) approach is taken as the reference, and as the methodological and instrumental framework. From the moment a person starts a migration process, social networks play an important role at both the point of departure and in the context of arrival. This relational framework appears to us as fundamental for the analysis and understanding of the evolution of educational paths which are subject to a restructuring process in terms of the student's relations and environments. Sandín and Pavón (2011), following along the same line as Lee (2009) for example, argue that social and personal networks of the population in general, and the immigrant population in particular, serve as indicators of social capital. These act as the starting point to both promote relational spaces and activate inclusive participatory ties, such as those needed to manage the integration processes in educational environments and the social fabric of the community.

Personal networks of immigrant adolescents are an example of how emigration can be understood as a process of relocation and incorporation of the social network of an immigrant minority into a wider and more structured host community (Maya-Jariego, 2009). The process depends heavily on the established links, connections with new people who can create relationships to facilitate the structuring of skilled networks and new sources of social support. Furthermore, we must not forget that everyday practices such as going to school, family, friends, etc. are already relational in themselves, and this is established as another element to be analysed in this context. Hence, the instrument presented in this article is based on the main premises of the SNA approach.

SNA moves from an attributive view of phenomena (an individual is the sum of variables: gender, age, etc.) towards a more complex understanding in which the study of the structure and function of networks (ties that people weave with other individuals, groups, associations, etc.) are essential. It is a broad intellectual approach (Molina, 2001) and specific methodological procedures and creative tools have been developed to measure, analyse and describe the structures, patterns and how interactions emerge from the relations between multiple social actors (individuals, organizations, countries...). There are two basic SNA approaches: a) the analysis of social networks (socio-centric approach) and b) the analysis of personal networks (egocentric approach). Particularly, this network tool is based on the egocentric approach, which is focused on the connections that can be traced from a given ego; the anchor and starting point for the analysis is the person so it focuses on the study of small personal networks from the perspective of the individual. Thus, this instrument allows us to highlight the actors and how they related to each other, and to study their attributes. Personal networks make up the social world of individuals, and an understanding of these could well be sufficient to explain the constraints they themselves impose, as well as the opportunities offered (Requena, 1996).

\section{Designing an Instrument}

Drawing together the analytical potentials of the concepts and approaches outlined above to measure and analyse the structures, patterns and forms of interactions that emerge from the links between different actors, this paper explains the development of an instrument to obtain personal networks, as part of a longitudinal research project (I+D+i EDU2011-25960). In this section, we present the objectives we hope to achieve with this questionnaire. 
Secondly, we outline the dimensions and indicators that shaped the final design. Finally, we describe the sample and the process followed in applying the tool within the framework of the project mentioned above.

\subsection{Aims of the Instrument}

The "Personal Network Questionnaire" (Sandín \& Sánchez, 2012) was generated with the primary objective of responding to the following:

1) To visualize the structure, composition and functionality of personal networks of students from immigrant families.

2) To describe the type of network and the potential social capital depending on the network type.

To address these objectives, and with use of graph theory, the questionnaire explores students' networks of relations in different relational contexts (school, family, neighbourhood, etc.) by constructing their personal network which incorporates various alteri and their characterization according to variables relevant for the study. An analysis of the student's personal network allows us, on the one hand, to visualize the different types of interpersonal relationships established, while also considering the other people (nodes) with whom he or she interacts. On the other hand, it allows us to analyse the resources provided by these interpersonal relations, particularly those which provide support and strength in daily life and/or crisis situations.

\subsection{Dimensions and Indicators of Analysis}

In the design of this type of instrument, the first methodological concern that arises is how to adequately generate the subset of relations of the student under investigation. The dimension in the questionnaire that allows us to elicit the relations of an individual is what we call the "name generator". This dimension includes the question that allows us to identify the persons comprising a subset (or social context) of the respondent's personal network, and therefore constitutes one of the most important questions in the questionnaire.

In our case, we were interested in visualising each student's personal network, identifying both strong and weak ties, and exploring how this network might affect academic achievements. Therefore, an open name generator, which allows both types of ties to be elicited, was selected (McCarty, 2002). Specifically, the name generator question in this study was: "List the people who are important to you, with whom you had contact this past year and who you think you will have contact with in the coming months. You can name as many people as you want. They can be anyone: family, school friends, teachers, monitors, member of a club you belong to, etc., with whom you talk about topics that interest or concern you; with whom you share leisure activities; who help or advise you; or others who for some reason are important to you. To help you make the list, try to visualise the things you do every day, taking into account the different areas of your life."

According to Requena (1996), Ferrand (1993) and Campbell and Lee (1991), the selection criterion is used so that the individual can list the people in his/her personal network based on the content of the relationship. Other criteria which could be used are those based on roles (i.e. relatives, friends, etc.) or the intensity of the relationship (those closest, most intimate, etc.).

Next to the dimension of "name generator", the instrument consists of five dimensions:

- Dimension 1: Name generator. This enables us to identify the people (alteri) who occupy one or more subsets of the personal network of the interviewee. This is one of the most important questions of the instrument to establish the subject's personal community.

- Dimension 2: Attributes of ego. It includes interviewee's sociodemographic and academic variables, which are relevant for the research purposes.

- Dimension 3: Attributes of alteri. Compiles variables that would facilitate characterisation of persons named in ego's network insofar as they are relevant for the study.

- Dimension 4: Relation between alteri and ego. Includes variables to specifically analyse the relationship between the young interviewee and each of the people in his/her personal network. Also, it includes the set of emotional and instrumental resources obtained from the interaction with others and which promote the well-being of the person in his/her environment. And finally, it seeks to capture the extent to which people within the personal network of each young person have influenced their academic development.

- Dimension 5: Relation between alteri. This allows us to see the network structure; thus, if the people with whom the ego has ties interact with each other. 
Table 1. Table of specifications and description of the dimensions of the network instrument developed

\begin{tabular}{|c|c|c|}
\hline Dimension & Indicator & Item \\
\hline 1. Name generator & $\begin{array}{l}\text { Persons from the different social contexts of the subject with whom he/she } \\
\text { maintains ties perceived as meaningful }\end{array}$ & - \\
\hline \multirow{6}{*}{ 2. Attributes of ego } & Sex & 1 \\
\hline & Age & 2 \\
\hline & Institute; group-class & $3-4$ \\
\hline & Origin; foreign origin & $5-6$ \\
\hline & Time resident in Barcelona & 7 \\
\hline & Academic expectations & 8 \\
\hline \multirow[t]{7}{*}{ 3. Attributes of alteri } & Sex; age; origin of alter & $9-11$ \\
\hline & Ties & 12 \\
\hline & Spheres of relations & 13 \\
\hline & Place of residence & 14 \\
\hline & Type of relation (personal...) & 15 \\
\hline & Frequency of relation & 16 \\
\hline & Intensity of the relation & 17 \\
\hline \multirow{8}{*}{$\begin{array}{l}\text { 4. Relation between } \\
\text { alteri and ego }\end{array}$} & Emotional support & 18 \\
\hline & Instrumental/tangible support & 19 \\
\hline & Advice and informative support & 20 \\
\hline & Positive feedback & 21 \\
\hline & Academic support & 22 \\
\hline & Social participation and company & 23 \\
\hline & Main support & 24 \\
\hline & Intensity of influence of alter in student engagement & 25 \\
\hline $\begin{array}{l}\text { 5. Relationship between } \\
\text { alteri }\end{array}$ & Relationship among alteri in absence of ego & 26 \\
\hline
\end{tabular}

Of all dimensions, we should draw special attention to the third. Here, as well as analysing in depth the relationship between ego and alteri (items 12-17), a sub-dimension of support (items 18-24) is also included. From the literature on networks and social capital, this is understood as a characteristic of the social networks from a psychosocial view of social capital (Caplan, 1974; Gracia, Herrero, \& Musitu, 2002; Lin, 1986; Maya-Jariego, Martínez, \& García, 1999). Support is understood as a set of emotional and instrumental resources that are obtained from the interaction with others, therefore from the relations that exist in social networks, and which help individuals to adjust to their environment, thus improving their well-being. Selecting the main contributions from some of the papers reviewed (Gracia, Herrero, \& Musitu, 2002; Lopez et al., 2007), this instrument analyses different aspects that encompass social support: a) contexts (community involvement, social networks and intimate relationships); b) type of support (informational, tangible and emotional); and c) the perceived reciprocity for each of these types of support. Another item was also included, which is of paramount interest to our study and in line with new research, the importance of social peer capital (Ream \& Rumberger, 2008; Swenson, Nordstrom, \& Hiester, 2008) in student engagement (item 25).

\subsection{Sample Population and Applying the Instrument}

The questionnaire was applied during the first phase of the project (Figure 1) with a sample of young immigrants or students of immigrant origin at three public schools in the province of Barcelona, in the towns of Sabadell, La Llagosta and Hospitalet de Llobregat. Specifically, the percentage of immigrant students at the education centres in Sabadell and La Llagosta in 2011-2012 was 15\%. This figure was notably higher in the Hospitalet de Llobregat school, reaching 59.8\%. The three institutes offer both compulsory education (ESO) and various 
post-compulsory modalities (Baccalaureate and CFGM), so students have the option to continue their education at the same school.

Using a non-probabilistic incidental sampling method, the initial sample included 87 young people from immigrant families who were doing the final year of compulsory secondary education $\left(4^{\text {th }}\right.$ year of ESO) in the 2011-2012 academic year. Of these, 51.1\% were boys and 48.8\% girls. Regarding the cultural and geographical origin of the participants, the study included all cultural groups present in the class, and participation was voluntary and informed. For this, the guidelines of the Code of Good Research Practice of the University of Barcelona (2010) were taken into consideration. The three largest groups in the sample were: $55.8 \%$ were from Latin America, 20.9\% from the Maghreb and 15.1\% from Catalonia or other parts of Spain. The others were: 4.7\% from other European countries, $2.3 \%$ from Asia, and 1.2\% in sub-Saharan Africa.

\begin{tabular}{|c|c|c|c|}
\hline \multirow{3}{*}{$\begin{array}{c}\text { Compulsory Secondary } \\
\text { Education (ESO) }\end{array}$} & \multirow[t]{3}{*}{ Transition risk } & \multicolumn{2}{|c|}{ Post-Compulsory Secondary Education (PO) } \\
\hline & & $\mathbf{1}^{\mathbf{0}}$ & $2^{\circ}$ \\
\hline & & & $\mathrm{n}=14$ \\
\hline Graduation & & & nic persistence \\
\hline
\end{tabular}

Figure 1. Longitudinal study design

The process of administering the questionnaire and contact with schools lasted about a month and a half (May-June 2012). Each of the students in the sample filled out the questionnaire at the schools selected for the study. Data were collected in situ using the free EgoNet (Egocentric Network Study Software) software program. Thus, 87 personal networks were observed, from which the network structure, the composition of their alteri, and functionality of their ties were analysed in a highly descriptive mode (Sánchez \& Sandín, 2013). By way of example, see the following figures plotting the networks of two students from Moroccan families (Figure 2 and 3 ). For details of the analysis, we suggest consulting the work of Borgatti, Everett, and Johnson (2013); Molina (2001); Scott and Carrington (2011) and Wasserman and Faust (1994). 


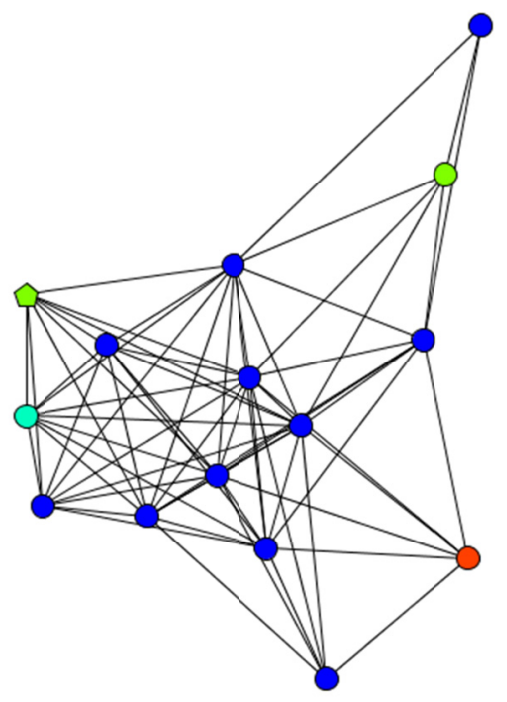

Figure 2. Personal network of a young person from a Moroccan family who abandoned his studies

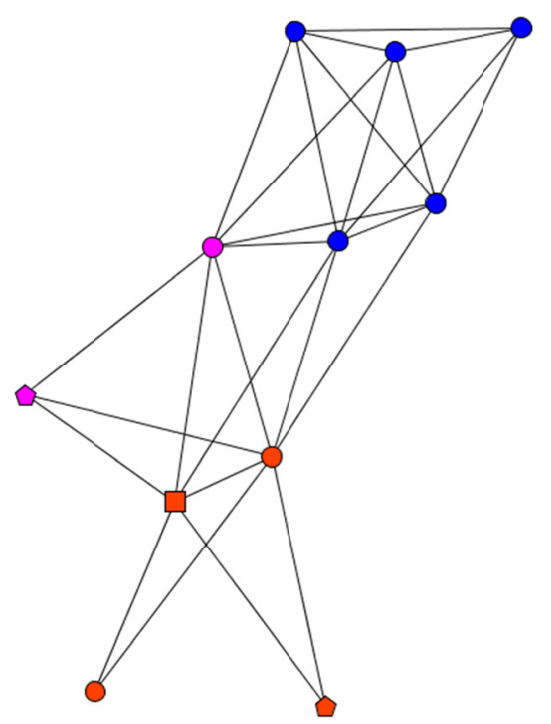

Figure 3. Personal network of a young person from a Moroccan family who continued with his studies
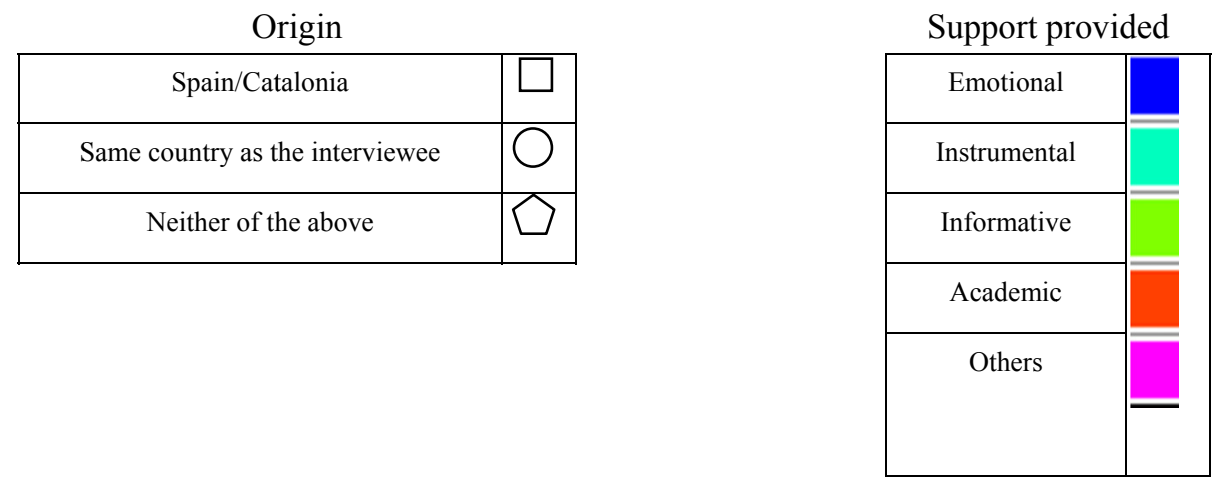

\section{Conclusions and Discussions}

SNA methodology and, in particular the visual representation of relationships, offers a great descriptive and explanatory power. In this study, the design of this type of instrument allows us to capture the entire set of relationships that students perceived as significant: family, school friends, friends, acquaintances and people they have met through participation in organizations, associations or other activities. It has also given us the ability to identify the formation of groups, the structure of the network, the positions of alteri and some of their attributes, as well as the perception these young people have of their relationships, depending on the different qualities of the links established, i.e. academic, emotional, instrumental support, etc.

Therefore, the two primary potentials of this instrument are: firstly, an exhaustive analysis of the type of contacts, relationships and networks of students of immigrant families in secondary education. Secondly, the discriminatory nature of the name generator question. Conversely, one of the limitations of this process is that this type of instrument requires major commitment in terms of time and personnel. Another limitation is the difficulty of the name generator question when interviewing adolescents.

Some of the methodological issues to be faced when developing an instrument of this nature relate to the formulation of the questions. As mentioned earlier, the first decision involves the characteristics of the network that we want to collect (size, frequency, context, intensity, etc.) and the content of what flows through the network. In terms of the latter, for example, in the support dimension, we start by asking some opening questions such as: How would they identify those who are sources of social support? Do all people provide support? How often do they seek support? Or what kind of support do these young people find in their relationships? And this leads on to questions about aspects such as availability of support (useful support, real support, perceived support) or types of support (emotional, informational, tangible, instrumental, positive feedback, social 
participation and company, etc.) that is hoped to be captured. Regarding the first point, we must consider whether the questions should be formulated for hypothetical, real or both situations. Meanwhile, in relation to the second aspect, we face the difficult task of defining and selecting those supports that can be contemplated within the framework of the study. It should also be noted that, unlike other instruments, each variable added is multiplied by the number of people that the subject has elicited, which greatly increases the complexity of the instrument and the time needed to administer it.

In the specific case of groups with academic vulnerability, such as the young people in this study, the network approach becomes highly significant and valuable, because as noted in the introduction, the need to teach the relational social capital (understood as the planning, development and evaluation of socio-educational activities that affect and modulate the configuration of social networks and social capital of students) is presented as a current educational challenge; graphic techniques can somehow address this challenge by examining the data and generating hypotheses (Freeman, 2005; Maya-Jariego \& Holgado, 2005). In this way, we can achieve a level of analysis of academic paths unexplored so far in the literature, and which appears in discussions as key to promoting equality and social cohesion in educational and social fields. Hypotheses can be tested by comparing this with other egocentric networks of young people who participated in this study. However, the questionnaire methodology for egocentric networks also includes a second phase based on a semi-structured interview, which is not discussed here due to space limitations. This would imply referring back to each person in the network and discussing each to establish the interpretation and attribution of the participants in the relational system (Izquierdo, 2011).

This type of tool and of analysis of social support networks may shed light on the contribution of the others, for example, in the academic success of young people, in major improvements in their educational pathways or increased likelihood of academic continuity. This is because networks play an important role in the flow of information and resources that otherwise people in vulnerable situations would be unlikely to find for themselves. However, we must not forget that other contextual and structural macro elements (conditions of the educational system and the labour market, educational policies and laws, etc.) may also strengthen or weaken the effect of networks on the educational success of these students (meso-level analysis). Therefore, although network analysis might be a necessary element to envision young people's academic pathways, these should not be analysed in isolation.

The results about the academic persistence of youth in this study with regard to their personal networks offer interesting lines to deepen in future diagnosis and educational intervention. We briefly discuss some of them such as the importance that young people give to have a close family structure and/or to get in touch with it. The context of the family appears as an important protective and supportive environment to their personal educational projects in their transition from compulsory education and through post-compulsory schooling. Friendships are revalued; it is not a time of great change regarding the number of friends, but in the type of relationship they have with their peers. In friendships they find trust, support, dialogue, understanding and love in times of difficulty and crisis. High dropout students showed that their exchanges with their peers were mainly focused on receiving and offering emotional support, while high success students exchanged also a great amount of information and academic support. These results are consistent with those found by Ream and Rumberger (2008) and Swenson, Nordstrom, and Hiester (2008), who claimed that "peer social capital" is a protective factor against dropout and fosters academic engagement. As for the size of the networks, it has also been seen a relationship between small and dispersed networks and school abandonment, so that actions such as mentoring programs (MBF, 2010; Rhodes \& Lowe, 2008) or service-learning (Luna, 2012) may contribute to broaden their networks and contexts of relationship. These and many other situations can be detected and explored on a personal level, giving professionals a contextual, detailed and systematic view of each young student and his/her environment (Ungar, 2012). This in turn facilitates the implementation of preventive programs and the optimization of relational environments, for instance, from the perspective of community planning academic intervention and educational orientation. Further research might also use the SNA methodology for those immigrants who study online and in the analysis of international mobility (Federico de la Rúa, 2003; Maya-Jariego, Cachia, Holgado, \& Ramos, 2014).

We believe that the theoretical and methodological approach presented here, as a factor that promotes continuation at school and academic success, should be the focal point of discussions regarding both academic and community planning interventions; particularly those designed to combat high dropout rates and academic failure. One of the main objectives of social and educational interventions should be the accompanying of young immigrants, and in general, the population at risk of social vulnerability, while generating and modulating their social capital. Professionals should not only consider personal networks characteristics (size, density, function 
and cultural perception), but also the type of social capital that a person has access to, and how this translates into potential or actual support in their academic development; and always with the intention of making changes to optimise this development.

\section{References}

Barrera, M. (1980). A method for the assessment of social support networks in community survey research. Connections, 3, 8-13.

Barrera, M., \& Ainley, S. L. (1983). The structure of social support: A conceptual and empirical analysis. Journal of Community Psychology, 11, 133-143. http://dx.doi.org/10.1002/1520-6629(198304)11:2<133::AID-JCOP2290110207>3.0.CO;2-L

Berstein, B. (1971). Class, codes and control; Vol. 1: Theoretical studies towards a sociology of language. London: Routledge \& Kegan Paul. http://dx.doi.org/10.4324/9780203014035

Berstein, B. (1973). Class, codes and control; Vol. 2: Applied studies towards a sociology of language. London: Routledge \& Kegan Paul.

Borgatti, S. P., Everett, M. G., \& Johnson, J. C. (2013). Analyzing social networks. London: Sage.

Bourdieu, P. (1986). The forms of capital. In J. G. Richardson (Ed.), Handbook of Theory and Research for the Sociology of Education (pp. 241-258). New York: Greenwood.

Bravo, A, \& Fernández, J. (2003). Las redes de apoyo social de los adolescentes acogidos en residencias de protección. Un análisis comparativo con población normativa. Psicothema, 15(1), 136-142.

Bridge, G. (2004). Perspectives on cultural capital and the neighbourhood. Urban Studies, 4, 719-730. http://dx.doi.org/10.1080/00420980600597392

Campbell, K. E., \& Lee, B. A. (1991). Name generators in surveys of personal networks. Social Networks, 13(3), 203-221. http://dx.doi.org/10.1016/0378-8733(91)90006-F

Cano, A. B. (2011). Procesos de integración y exclusión social juvenil en las periferias de Barcelona y Milán (Tesis doctoral, Barcelona: Universitat de Barcelona, España).

Cano, A. B., Sánchez, A., \& Sandín, M. P. (2014). Retomando los debates del capital social para promocionar el éxito educativo de los alumnos de origen inmigrante. Revista Ábaco, 82(4), 108-112.

Caplan, G. (1974). Support systems and community mental health: Lectures on concept development. New York: Behavioral Publications.

Chow, H. (2000). The determinants of academic performance: Hong Kong immigrant students in Canadian schools. Canadian Ethnic Studies, 32(3), 105-110.

Coleman, J. (1988). Social capital in the creation of human capital. American Journal of Sociology, 94, 95-120. http://dx.doi.org/10.1086/228943

Federico de la Rúa, A. de. (2003). La dinámica de las redes de amistad. La elección de amigos en el programa Erasmus. Redes: Revista hispana para el análisis de redes sociales, 4(3). Retrieved from http://revista-redes.rediris.es/html-vol4/vol4_3.htm

Fernández-Enguita, M., Mena, L., \& Riviere, J. (2010). Fracaso y abandono escolar en España. Barcelona: Obra Social Fundació La Caixa.

Ferrand, A. (1993). L'Analyse des réseaux personnels. HDR: Université de Lille I.

Freeman, L. C. (2005). Graphic techniques for exploring social network data. In P. J. Carrington, J. Scott, \& S. Wasserman (Eds.), Models and methods in social network analysis (pp. 248-269). New York: Cambridge University Press. http://dx.doi.org/10.1017/CBO9780511811395.012

Gibson, M. A., \& Carrasco, S. (2009). The education of immigrant youth: some lessons from the U.S. and Spain. Theory Into Practice, 48, 249-257. http://dx.doi.org/10.1080/00405840903188118

Gil-Calvo, E. (2009). Trayectorias y transiciones: Qué rumbos? Revista Estudios de Juventud, 87, 15-29.

Godoy, M. J., Suárez, A., \& Lucas, M. G. (2011). La inclusión social del alumno inmigrante y el aprendizaje de la L2, como nuevo reto para el profesorado. XII Congreso Internacional de Teoría de la Educación. Universitat de Barcelona. Barcelona.

Gottlieb, B. H. (1978). The development and application of a classification scheme of informal helping behaviours. Canadian Journal of Behavioural Science, 10, 105-115. http://dx.doi.org/10.1037/h0081539 
Gracia, E., Herrero, J., \& Musitu, G. (2002). Evaluación de recursos y estresores psicoso-ciales en la comunidad. Madrid: Síntesis.

Granovetter, M. (1973). The strength of weak ties. American Journal of Sociology, 78, 1360-1380. http://dx.doi.org/10.1086/225469

Gualda, E. (2004). Actitudes hacia las migraciones y capital social: la participación de los europeos en redes sociales y sus lazos con la mayor o menor aceptación de la población extranjera. Redes: Revista hispana para el análisis de redes sociales, 7(3). Retrieved from: http://revista-redes.rediris.es/html-vol7/vol7_3.htm

Izquierdo, R. (2011). Jóvenes vulnerables a la entrada del mercado de trabajo: visualización de ego-redes en Talleres Prelaborales de la Zona Norte de Sevilla. Redes: Revista hispana para el análisis de redes sociales, 21(12). Retrieved from: http://revista-redes.rediris.es/html-vol21/vol21_12.htm

Lee, M. (2009). Decoding effects of micro social contexts on the academic achievement of immigrant adolescents form the poor working-class: Peers, institutional agents, and schools contexts. Minnesota: University of Minnesota.

Lin, N. (1986). Conceptualizing social support. In N. Lin, A. Dean, \& W. Ensel (Eds.), Social support, life events, and depression (pp. 17-30). New York: Academic Press. http://dx.doi.org/10.1016/B978-0-12-450660-2.50008-2

López, I., Menéndez, S., Lorence, B., Jiménez, L., Hidalgo, M. V., \& Sánchez, J. (2007). Evaluación del apoyo social mediante la escala ASSIS: Descripción y resultados en una muestra de madres en situación de riesgo psicosocial. Psychosocial Intervention, 16(3), 323-338.

Luna, E. (2012). Service learning experience for the development of inclusion. In T. Murphy (Coord.), Service learning and educating in challenging contexts: International perspectives (pp. 157-172). London: The Continuum Publishing Company.

Marí-Klose, P. (2014). Combatir la desigualdad: Una cuestión de eficiencia. El diario.es. Retrieved from http://www.eldiario.es/agendapublica/impacto_social/Combatir-desigualdad-cuestion-eficiencia_0_3366665 44.html

Martínez-Ambite, A. (2012). Trayectorias formativas. Alumnado inmigrante. Madrid: Secretaría Políticas Sociales.

Martínez-Celorrio, X., \& Marín-Saldo, A. (2010). Educació i ascens social a Catalunya. Barcelona: Fundació Jaume Bofill.

Martínez, M., García, M., \& Maya-Jariego, I. (2001). El rol del apoyo social y las actitudes hacia el empleo en el emplazamiento laboral de inmigrantes. Anuario de Psicología, 32(3), 51-65.

Maya-Jariego, I. (2009). Mallas de paisanaje: el entramado de relaciones de los inmigrantes. Redes: Revista hispana para el análisis de redes sociales, 17(13), 273-303. Retrieved from http://revistes.uab.cat/redes/article/view/385/256

Maya-Jariego, I., \& Holgado, D. (2005). Lazos fuertes y proveedores múltiples de apoyo: Comparación de dos formas de representación gráfica de las redes personales. Empiria: Revista de metodología de Ciencias Sociales, 10, 107-128.

Maya-Jariego, I., Cachia, R., Holgado, D., \& Ramos, I. (2014). Visualización del apoyo social en las redes personales de los inmigrantes. Cachiers, 5, Serie FabricaMig. SA. México: Centro de Estudios Mexicanos y Centroamericanos (CEMCA).

Maya-Jariego, I., Martínez, M. F., \& García, M. (1999). Cadenas migratorias y redes de apoyo social de las mujeres peruanas en Sevilla. Demófilo. Revista de Cultura Tradicional de Andalucía, 29, 87-105.

McCarty, C. (2002). Structure in personal networks. Journal of Social Structure, 3(1), 1-19. Retrieved from http://www.cmu.edu/joss/content/articles/volume3/McCarty.html

Mentoring Befriending Foundation (MBF). (2010). Peer mentoring in schools: A review of the evidence base of the benefits of peer mentoring in schools including findings from the MBF Outcomes Measurement Programme. Manchester: Mentoring Befriending Foundation.

Ministerio de Educación, Cultura y Deporte e Instituto Nacional de Evaluación Educativa. (2013). PISA 2012. Programa para la Evaluación Internacional de los Alumnos. Volumen I: Resultados y contexto. Madrid: Ministerio de Educación, Cultura y Deporte. Retrieved from 
http://www.mecd.gob.es/dctm/inee/internacional/pisa2012/pisa2012lineavolumeni.pdf?documentId=0901e7 2b81786310

Molina, J. L. (2001). El análisis de redes sociales. Una introducción. Barcelona: Edicions Bellaterra.

Organisation for Economic Co-operation and Development (OECD). (2014). Education at a glance 2014: OECD Indicators. Paris: OECD Publishing. http://dx.doi.org/10.1787/eag-2014-en_

Portes, A. (1995). Economic sociology and the sociology of immigration. A conceptual overview. In A. Portes (Ed.), The economic sociology of immigration: Essays on the networks, ethnicity and entreprenership (pp. 1-41). New York: Russell Sage Foundation.

Portes, A. (1998). Social capital: its origins and applications in modern sociology. Annual Review of Sociology, 24(1), 1-24. http://dx.doi.org/10.1146/annurev.soc.24.1.1

Portes, A., \& MacLeod, D. (1999). Educating the second generation: determinants of academic achievement among children of immigrants in the United States. Journal of Ethnic and Migration Studies, 25(3), 373-396. http://dx.doi.org/10.1080/1369183X.1999.9976693

Putnam, R. D. (1993). Making democracy work: civic traditions in modern Italy. Princeton: Princeton University Press.

Ream, R. K., \& Rumberger, R. W. (2008). Student engagement, peer social capital, and school dropout among Mexican American and non-latino white students. Sociology of Education, 81, 109-139. http://dx.doi.org/10.1177/003804070808100201

Requena, F. (1996). Redes sociales y cuestionarios. Colección Cuadernos Metodológicos, 18. Madrid: Centro de Investigaciones Sociológicas.

Rhodes, J., \& Lowe, S. R. (2008). Youth mentoring and resilience: Implications for practice. Child Care in Practice, 14(1), 9-17. http://dx.doi.org/10.1080/13575270701733666

Salido, O. (2007). El Informe PISA y los retos de la educación en España. Retrieved from http:/www.falternativas.org/en/laboratorio/documentos/documentos-de-trabajo/el-informe-pisa-y-los-retosde-la-educacion-en-espana

Sánchez, A., \& Sandín, M. P. (2013). Joves immigrants i persistència acadèmica: què ens diuen les seves xarxes personals? Temps d'Educació, 44, 177-190.

Sandín M. P., \& Pavón, M. A. (2011). Immigration, social support, and community from a relational perspective. In W. Walter, \& D. Manschke (Eds.), Tolerance and education in multicultural societies (pp. 125-140). Frankfurt: Peter Lang.

Sandín, M. P., \& Sánchez, A. (2012). Cuestionario de redes personales. Red amplia. Barcelona: Dipòsit Digital de la Universitat de Barcelona. Retrieved from http://diposit.ub.edu/dspace/handle/2445/34579

Scott, J., \& Carrington, P. J. (2011). The Sage handbook of social network analysis. London: Sage. http://dx.doi.org/10.1007/s13278-010-0012-6

Serra, C., \& Palaudàrias, J. M. (2010). Deficiencias en el seguimiento del abandono escolar y trayectorias de continuidad del alumnado de origen inmigrado. Revista de Educación, 370 (número extraordinario 2010), 283-305.

Swenson, L. M., Nordstrom, A., \& Hiester, M. (2008). The role of peer relationships in adjustment to college. Journal of College Student Development, 49(6), 551-567. http://dx.doi.org/10.1353/csd.0.0038

Ungar, M. (2012). The social ecology of resilience: $A$ handbook. New York, NY: Springer. http://dx.doi.org/10.1007/978-1-4614-0586-3

Universitat de Barcelona. (2010). Codi de bones pràctiques en recerca. Barcelona: Agència de Polítiques i de Qualitat de la Universitat de Barcelona.

Urban, S. (2009). Is the neighbourhood effect an economic or an immigrant issue? A study of the importance of the childhood for future integration into the labour market. Urban Studies, 46, 583-603. http://dx.doi.org/10.1177/0042098008100996

Wasserman, S., \& Faust, K. (1994). Social network analysis: methods and applications. Cambridge: Cambridge University Press. http://dx.doi.org/10.1017/CBO9780511815478

Weller, S., \& Bruegel, I. (2009). Children's 'place' in the development of neighbourhood social capital. Urban 
Studies, 46, 629-643. http://dx.doi.org/10.1177/0042098008100998

\section{Note}

Note 1 . This text is part of a longitudinal $\mathrm{R}+\mathrm{D}+\mathrm{i}$ project which aims to determine the extent to which personal and social networks can empower immigrant students, providing them with a promoting or protective factor in their academic pathways, thereby affecting how long they remain at school or their academic success. The title of this project is: "Successful pathways of foreign students attending Compulsory to Post-compulsory secondary education: a longitudinal study using a network approach (EDU2011-25960), funded by the Ministry of Economy and Competitiveness, Government of Spain.

\section{Copyrights}

Copyright for this article is retained by the author(s), with first publication rights granted to the journal.

This is an open-access article distributed under the terms and conditions of the Creative Commons Attribution license (http://creativecommons.org/licenses/by/3.0/). 